\title{
GROUNDWATER MANAGEMENT NORTH OF SHARKIA GOVERNORATE (EGYPT)*
}

\author{
Ahmed H. El-sayed ${ }^{1}$, Nahed E. Elaraby ${ }^{2}$, Akram M. Fekry ${ }^{2}$, Mohamed F. Hendy ${ }^{2} * *$ \\ ${ }^{1}$ Water \& Water Structures Eng. Dept., Zagazig University, Egypt \\ ${ }^{2}$ Groundwater Research Institute, NWRC
}

\begin{abstract}
Egypt is one of the countries facing great challenges due to its limited water resources represented mainly by its fixed share of the Nile water and its aridity as a general characteristic. Therefore developing other water resources, of which groundwater is the most important, for irrigation, domestic and industrial uses is necessary to meet increasing water demands. The groundwater development is controlled mainly by economic and quality considerations. The groundwater aquifer located below Sharkia governorate is taken as the case study. The project area is located at latitude $32.5^{\circ} \mathrm{N}$ and $30^{\circ}$ longitudinal at an elevation of $10 \mathrm{~m}$ above the mean sea level. Special reference is made to groundwater evaluation, and present and future utilization. A variety of groundwater development schemes have been implemented to supplement surface water deficits or to solve drainage problems. This article is an attempt to give a brief review on the status of eastern delta aquifer, present, and future plans for groundwater development that are usually based on the hydrogeological characteristics of the groundwater aquifer. In this paper, Simulation model has been applied to produce different operational scenarios for Groundwater aquifer by using simulation software (Modflow) under Sharkia Directorate, Egypt. The simulated model has been used to study the effect of increasing in groundwater discharge under different policies of optimal water resources management in Sharkia Directorate. The model enables the water planner/manager to evaluate and choose the most suitable operation guidelines for the local conditions and objectives.
\end{abstract}

KEY WORDS: Optimal Water Resources Management, Groundwater, Sharkia Governorate, Eastern Delta Aquifer.

\section{GESTION DES EAUX SOUTERRAINES NORD DE SHARKIA GOUVERNORAT (EGYPTE)}

\section{RÉSUMÉ}

L'Egypte est l'un des pays confrontés à de grands défis en raison de ses ressources limitées en eau représentée principalement par sa part fixe de l'eau du Nil et de son aridité comme une caractéristique générale. Par conséquent le développement d'autres ressources en eau, dont les eaux souterraines est le plus important, pour l'irrigation, les usages domestiques et industriels est nécessaire pour répondre à la demande en eau croissante. Le développement des eaux souterraines est contrôlée principalement par des considérations économiques et de qualité. La nappe aquifère située au-dessous Sharkia gouvernorat est considéré comme l'étude de cas. La zone du projet se situe à une latitude de $32,5^{\circ} \mathrm{N}$ et $30^{\circ}$ longitudinale à une altitude de $10 \mathrm{~m}$ au-dessus du niveau moyen des mers. Une référence spéciale est faite à l'évaluation des eaux souterraines, et de l'utilisation actuelle et future. Une variété de programmes de développement des eaux souterraines ont été mises en œuvre pour compléter les déficits en eau de surface ou pour résoudre des problèmes de drainage. Cet article est une tentative de donner un bref aperçu sur l'état de l'est du delta du aquifère, présents et futurs plans de développement des eaux souterraines qui sont habituellement fondées sur les caractéristiques hydrogéologiques de l'aquifère. Dans ce papier, le modèle de simulation a été appliquée pour produire différents scénarios opérationnels de nappes aquifères souterraines en utilisant des logiciels de simulation (Modflow) sous la direction de Sharkia, en Egypte. Le modèle de simulation a été utilisée pour étudier l'effet de l'augmentation du débit des eaux souterraines dans les différentes politiques de gestion de l'eau optimale dans Sharkia Direction. Le modèle permet au gestionnaire de l'eau planificateur / pour évaluer et choisir les directives opération la plus adaptée aux conditions locales et des objectifs.

MOTS-CLES: Optimal gestion des ressources hydriques, des eaux souterraines, Sharkia Gouvernorat, de l'Est du delta aquifère.

\footnotetext{
* Received: 23 / 10 / 2011, Accepted: 18/ 12 / 2011 (Technical report)
}

** Contact author (eng.m.hendy83@ hotmail.com, +2 0114 9955473) 


\section{INTRODUCTION}

Water resources in Egypt are becoming scarce. Surface-water resources originating from the Nile are now fully exploited, while groundwater sources are being brought into full production. Egypt is facing increasing water needs, demanded by a rapidly growing population, by increased urbanization, by higher standards of living and by an agricultural policy which emphasizes expanded production in order to feed the growing population. The population is currently increasing by more than one million people a year. With a population of approximately 55 million in 1994, Egypt is expected to see an increase to about 115 million by 2025. Improved planning and management procedures to appropriate, allocate and use water are key measures generally prescribed to make the optimum use of available water. Study area is located in the north of Sharkia irrigation directorate and falls between two drains Bahr El-Baqar drain \& Bahr Hados drain and Bahr Muweis canal passes in between them, The problem is how to manage groundwater in the northern governorate and how to determine the optimal exploitation of underground water storage and development of policies. The aim is to determine the quantities of withdrawing security during the coming stage in anticipation continuing to increase the water needs of population, agricultural and industrial purposes for comprehensive development.

\section{MODEL DESCRIPTION}

(Integrated Modeling Environment for MODFLOW, MODPATH, MT3D)

Visual MODFLOW provides professional 3D groundwater flow and contaminant transport modeling using MODFLOW-2000, MODPATH, MT3DMS and RT3D. Visual MODFLOW Pro combines the standard Visual MODFLOW package with Win PEST and the Visual MODFLOW 3D-Explorer to give the most complete and powerful graphical modeling environment available. This fully-integrated groundwater modeling environment allows to:

- graphically design the model grid, properties and boundary conditions.

- visualize the model input parameters in two or three dimensions.

- run the groundwater flow, path line and contaminant transport simulations.

- automatically calibrate the model using Win PEST or manual methods, and Display and interpret the modeling results in threedimensional space using The Visual MODFLOW 3D-Explorer.

Considering the large variability and the quick development of groundwater models, a new, more sophisticated model can often replace a previously applied model. Additionally, the reconsideration of the conceptual model and the regeneration of the mesh may need a new allocation of the parameters. Therefore, it is important that model data (information) are stored independently from a given model, with a preference for GIS-based databases.

\section{STUDY AREA}

Nile Delta is considered one of the most important water resources in Egypt, which is essentially to face the increase in water requirements, this aquifer belongs mainly to the Quaternary age, it is formed from fluviomarine deposits and Deltaic deposits, the aquifer is composed generally of unconsolidated sand and gravel with occasional clay lenses that increases toward northern direction. 
Study area is located at the north of Sharkia Irrigation Directorate of Egypt. The area is bounded by latitudes $30^{\circ}$ $30^{\circ}$ and $31^{\circ} 00^{\circ} \mathrm{N}$, and longitudes $31^{\circ}$ 30 and $32^{\circ} 00^{\circ} \mathrm{E}$ Covering an area of about $1200 \mathrm{~km}^{2}$.

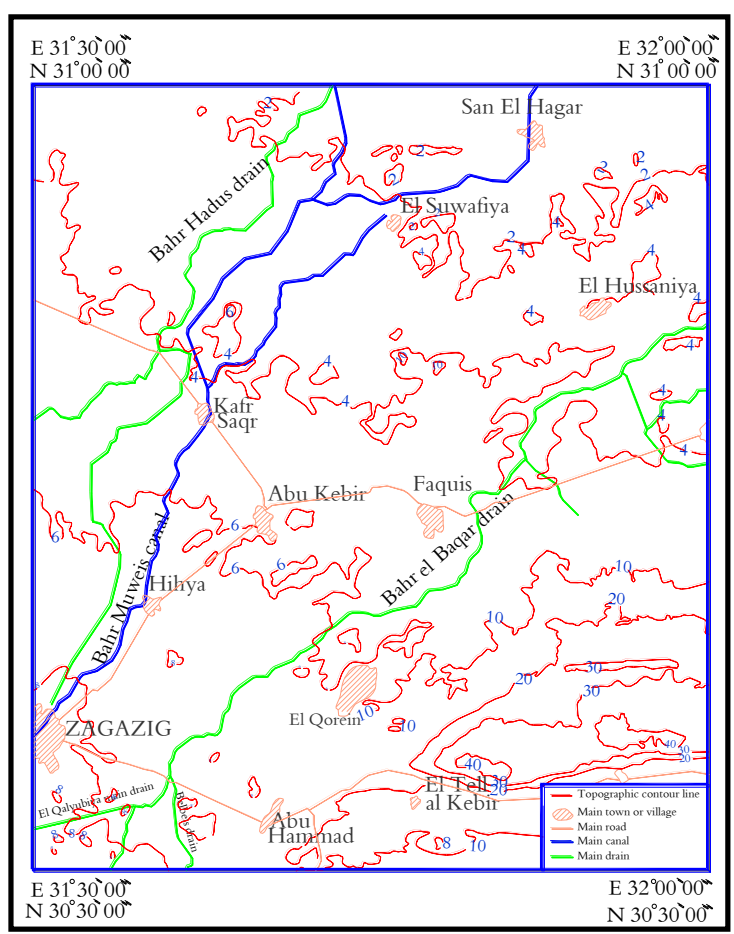

Fig. 1: Topographic contour map of the study area.

The area is characterized by semi-flat, sloping gently northwards, with elevation of $(+13 \mathrm{~m})$ at southern portion, the area then moves with an average slope of $1 \mathrm{~m}: 5.3 / \mathrm{km}$ until reaching a level of $(+1 \mathrm{~m})$ near Manzala lake. With an average level of $(+6 \mathrm{~m})$, the mid line of the study area represents the lowest part, the level increases to east and west directions. Fig. (1) shows the topographic map of the study area, based on data from Zagazig Hydrogeological map second edition (1991), scale 1:100000.

The land use map for study area locality is shown in Fig. (2) shows the surface view of locality representing the main canals and drains, cultivated lands surface irrigated, groundwater or by both, town's and villages, and desert areas.

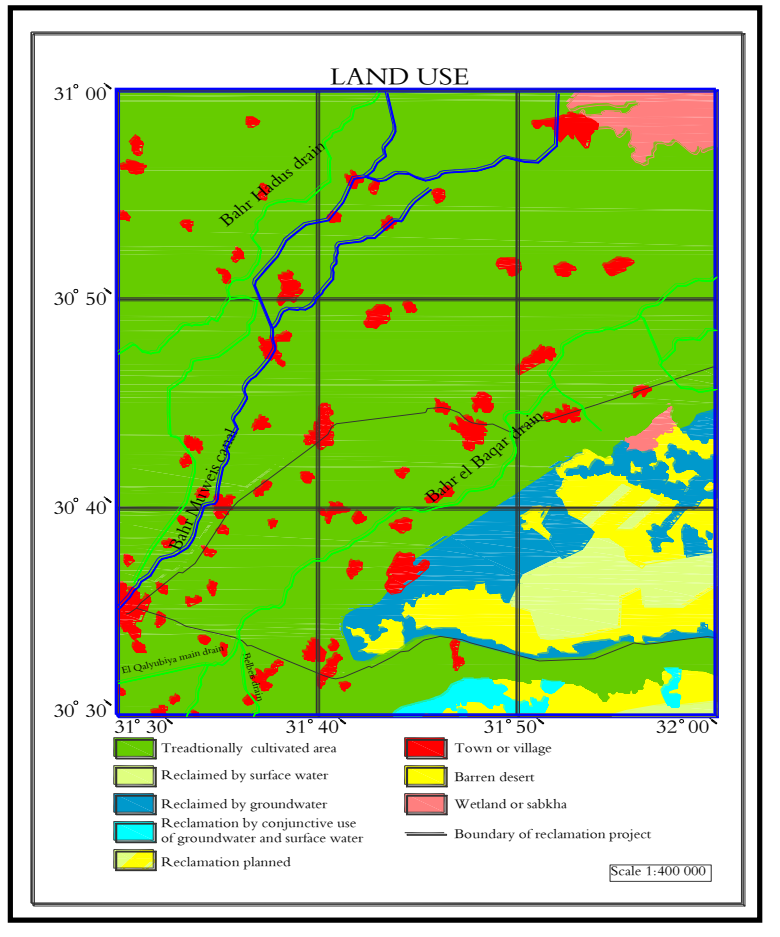

Fig. 2: Land use map of the study area

The study area is bounded by two main drains Bahr El Baker drain from the east and Bahr Hadous drain from the west. As shown in Fig. (3), Bahr El Baker is considered the biggest drain in Egypt, which represent the main sewer of Cairo, the drain starts near Belbies as an extension for two drains, El Kalubia Drain that brings waste water from Cairo city, also it collects water coming from Belbies drain. Bahr El Baker then moves north east until reaching Manzala Lake, with a length equals $85 \mathrm{~km}$. Bahr Hadous drain starts at the north of Benha city, east of ElRaiah El-Tawfeiki and is directed to north east with an average length of $50 \mathrm{~km}$ reaching Manzala Lake (Table 1). 


\section{Helmy, Elaraby, Fekry, Hendy}

The geology of the Nile Delta is given starting with the Basement (Pre-camberian 2000 million years), the ancient life era (Paleozoic ... 600 million years), the middle life era (Mesozoic ...185 million years), and the recent life era (Cenozoic ... 60 million years), taking into consideration all interesting as - aspects of hydrophysiography, hydrostructure and hydrostratigrasphy. The Delta is covered with Holocene Nile alluvium (10000 years), ), Fig. 4 shows the clay thickness in the study area. The level of the delta land ranges between $(+17 \mathrm{~m})$, above sea level at the south to one meter or less at the north boundaries. The range of its land slope is one meter $/ 8.5 \mathrm{~km}$ approximately.

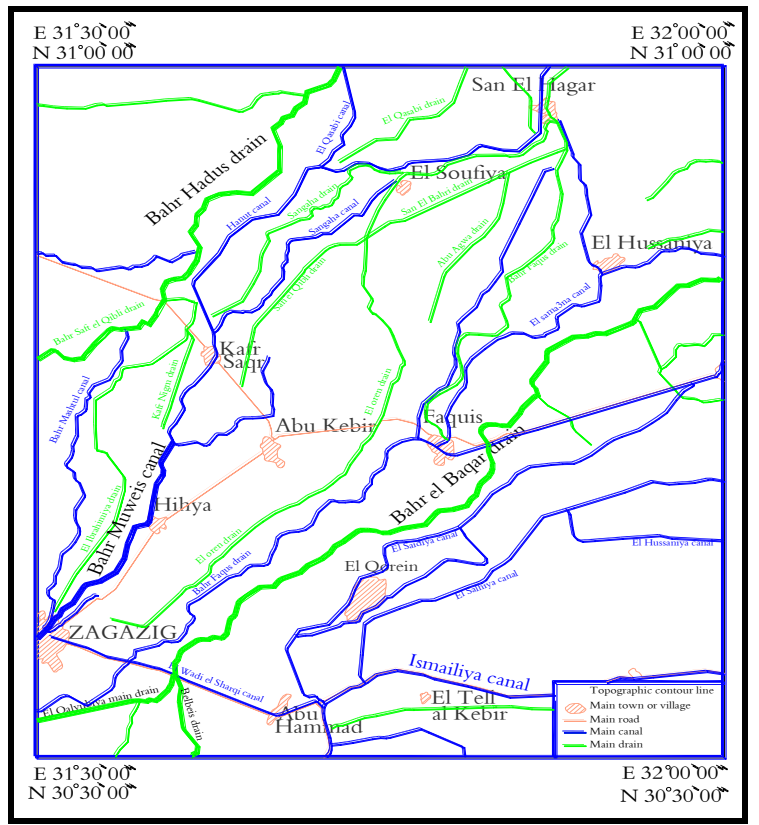

Fig. 3: Main canals and drains

Table (1): Main canals and drains in the study area

\begin{tabular}{|c|c|c|c|c|c|c|c|}
\hline $\begin{array}{c}\text { The Nile Branch, } \\
\text { Canals, Drains } \\
\text { and lakes }\end{array}$ & $\begin{array}{c}\text { Total } \\
\text { length } \\
\text { in (km) }\end{array}$ & \multicolumn{2}{|c|}{ Extension } & $\begin{array}{c}\text { Bottom level } \\
\text { at mouth in } \\
(\mathrm{m})\end{array}$ & $\begin{array}{c}\text { Ranges of } \\
\text { bottom } \\
\text { width in (m) }\end{array}$ & $\begin{array}{c}\text { Mean } \\
\text { depth of } \\
\text { water (m) }\end{array}$ & $\begin{array}{c}\text { Ranges of } \\
\text { surface water } \\
\text { level in (m) }\end{array}$ \\
\cline { 3 - 8 } El Ismailya Canal & 136 & $\begin{array}{c}\text { Nile, } \text { km 7 } \\
\text { north Cairo }\end{array}$ & $\begin{array}{c}\text { El Temsah } \\
\text { lakes }\end{array}$ & 10.75 & $10-30$ & 5 & $0.0-16.0$ \\
\hline $\begin{array}{c}\text { Bahr El Bakar } \\
\text { drain }\end{array}$ & 85 & $\begin{array}{c}\text { Abu } \\
\text { Hammad }\end{array}$ & $\begin{array}{c}\text { El Manzala } \\
\text { lake }\end{array}$ & - & $10-20$ & 5 & $0.35-0.48$ \\
\hline $\begin{array}{c}\text { Bahr Hadous } \\
\text { drain }\end{array}$ & 50 & Kafr Saqr & $\begin{array}{c}\text { El Manzala } \\
\text { lake }\end{array}$ & - & $5-40$ & 5 & $0.35-0.5$ \\
\hline
\end{tabular}


The quaternary aquifer base level in the study area ranges between $(-320 / \mathrm{m})$ to $(-360 / \mathrm{m})$ under the mean sea level increasing gradually to the north direction Fig. 5 shows the groundwater head in the study area.

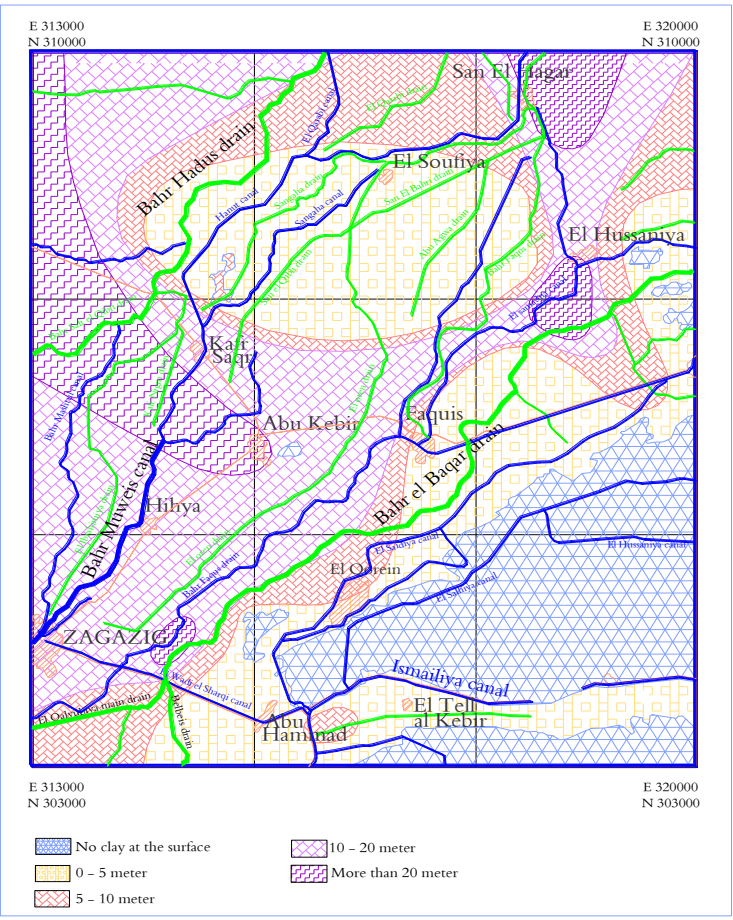

Fig. 4: Clay thickness in the study area

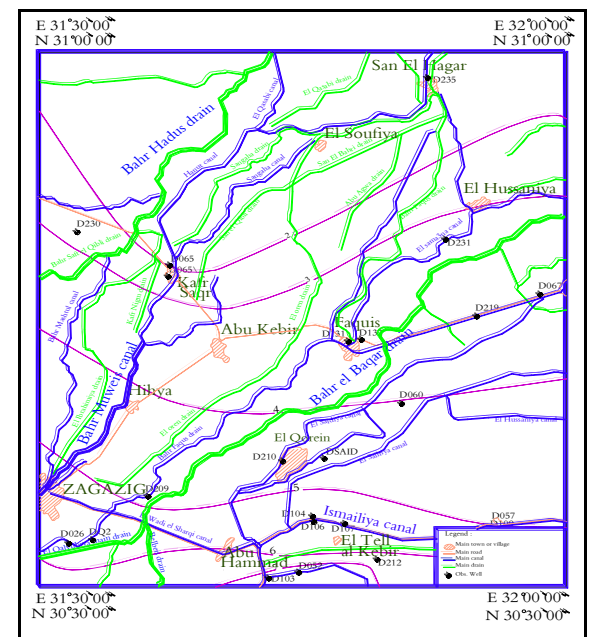

Fig. 5: Groundwater Head in the study area

\section{AQUIFER SIMULATION, CALIBRATION, AND ANALYSIS OF RESULTS}

The operation of the numericals model in the case of consistency (steady state) were applied. The simulation head and flow results are shown in Figs. 6 and 7 . Calibrate of the simulated head is made in comparison with the observed average levels of the groundwater monitored in observation wells.

The feed rates of the reservoir has been calibrated and even reached to the maximum possible accuracy. Fig. (8) shows a comparison between calculated and observed head. Fig. (9) shows a plot of mass water balance of the groundwater reservoir.

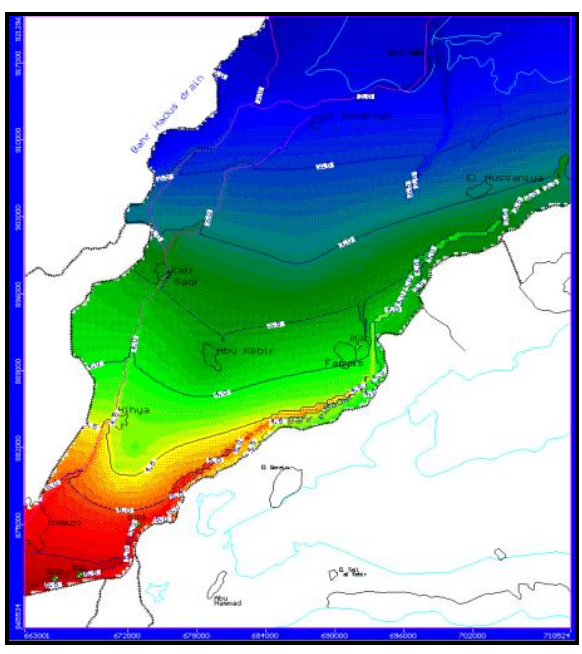

Fig. 6: Simulated head 


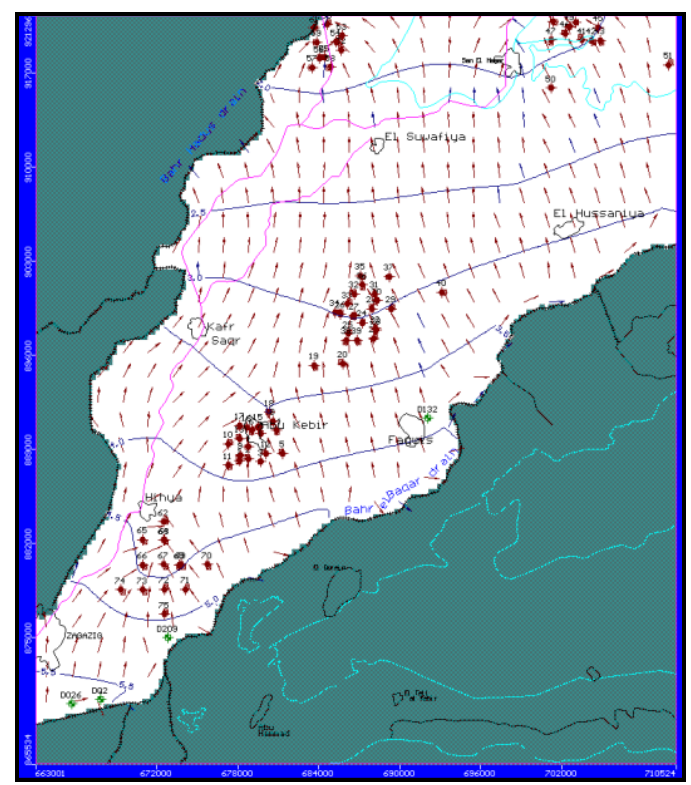

Fig. 7: Groundwater flow direction

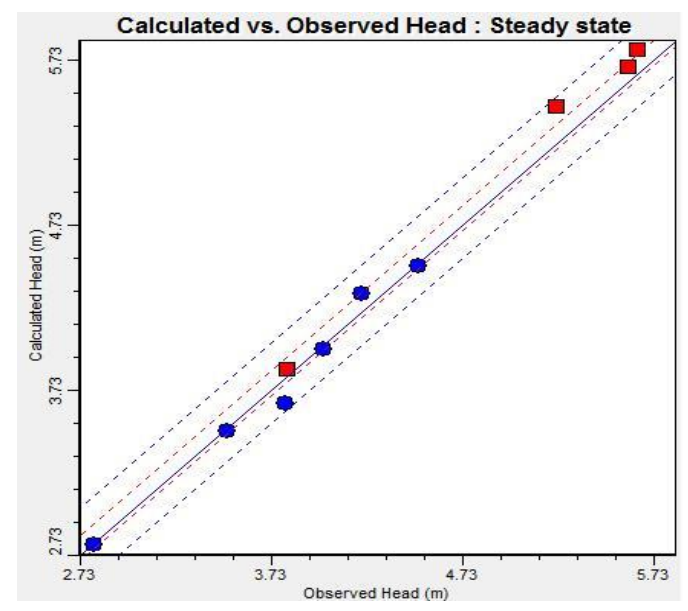

Fig. 8: Comparison between calculated and observed heads

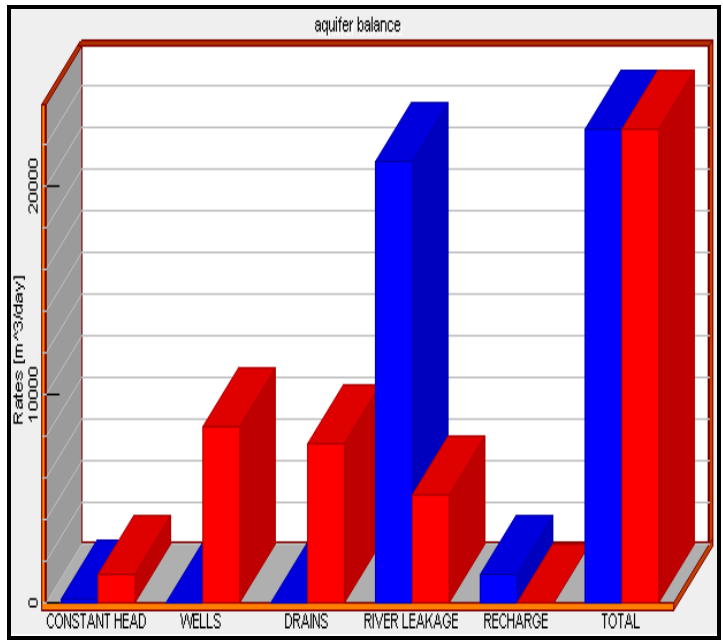

Fig. 9: Calibration of the aquifer mass balance

As shown from Fig. (8), a good correlation exists between the calculated and observed pizometric heads, indicating the accuracy of the simulation model. 
After calibration, the model was applied to study the future operation scenarios to study the effect of change in well's discharge on the groundwater head through different location. Figs. 10 and 11 show's the drawdown after increasing the discharge with $5 \%$, and with $10 \%$, respectively.

Table 2: Difference between measured and calculated groundwater levels

\begin{tabular}{|c|c|c|c|c|}
\hline \multirow{2}{*}{$\mathbf{N}$} & \multirow{2}{*}{ Well No. } & \multicolumn{2}{|c|}{$\begin{array}{l}\text { underground water level } \\
\qquad \text { (m) }\end{array}$} & \multirow{2}{*}{$\begin{array}{c}\text { Variance } \\
\text { (m) }\end{array}$} \\
\hline & & Calculated & measured & \\
\hline 1 & D132/1 & 3.86 & 3.81 & -0.05 \\
\hline 2 & D209/1 & 5.45 & 5.22 & -0.23 \\
\hline 3 & DQ2/1 & 5.79 & 5.59 & -0.2 \\
\hline 4 & D026/1 & 5.69 & 5.64 & -0.05 \\
\hline 5 & D1/2 & 3.48 & 3.5 & 0.02 \\
\hline 6 & D2/2 & 3.98 & 4 & 0.02 \\
\hline 7 & D3/2 & 4.48 & 4.5 & 0.02 \\
\hline 8 & D4/2 & 2.79 & 2.8 & 0.01 \\
\hline 9 & D5/2 & 4.31 & 4.2 & -0.11 \\
\hline 10 & D6/2 & 3.65 & 3.8 & 0.15 \\
\hline
\end{tabular}

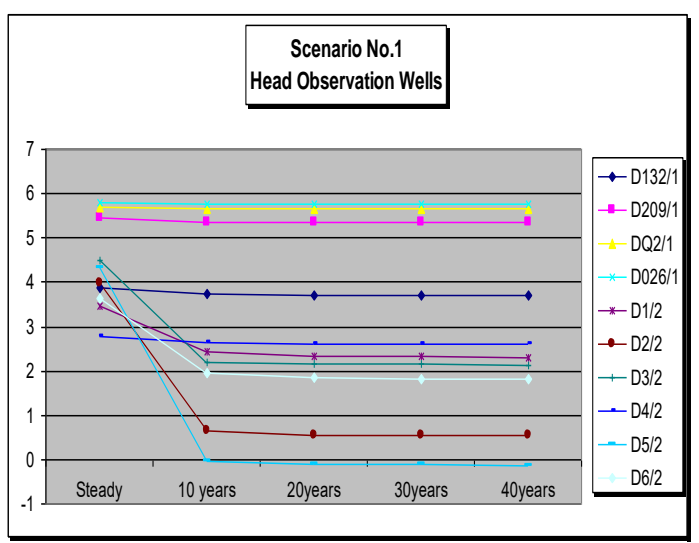

Fig. 10: Head in observation wells with discharge increased by $\mathbf{5 \%}$

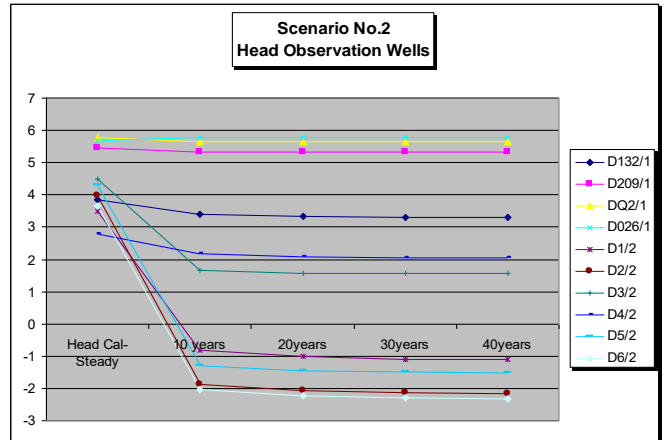

Fig. 11: Head in observation wells with discharge increased by $10 \%$

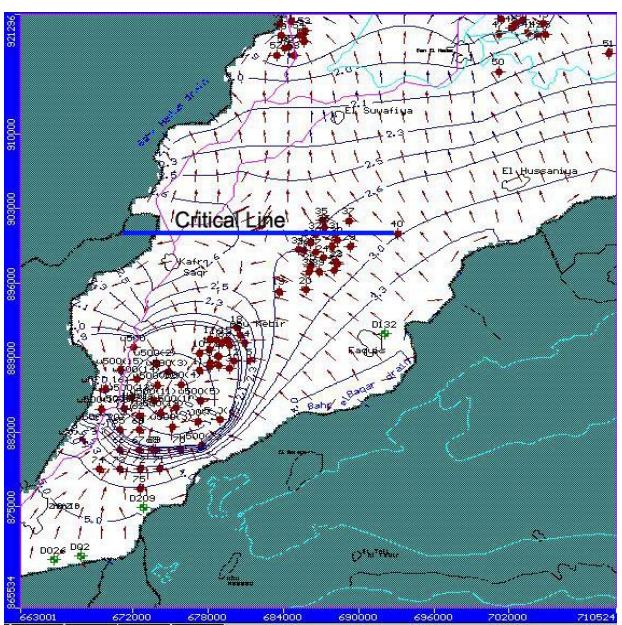

Fig. (12): 5\% Increase in extraction

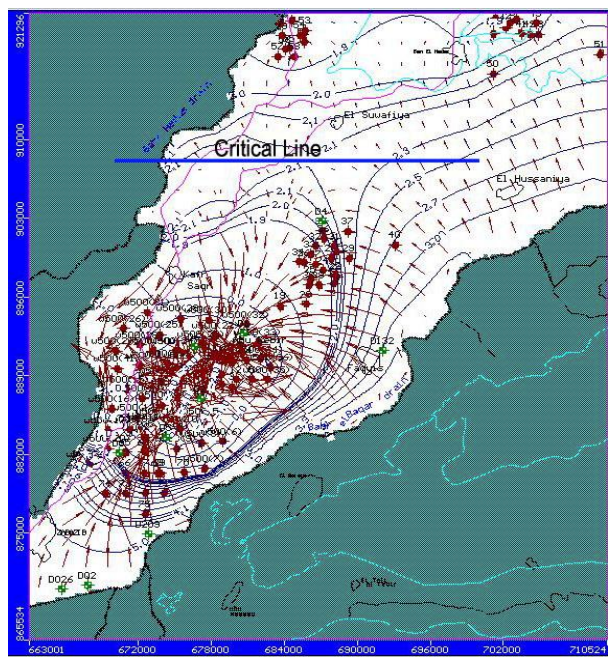

Fig. (13): 10\% Increase in extraction 


\section{CONCLUSIONS}

Development of an operation model in the field of water resources management to helps water resources engineers, hydrologists, and policy makers take decision in operation and management of available water resources to meet water demands the optimal value of water deficits.

The developed model may be used to perform evaluation for the present water strategy under the given operation rules.

The developed model can be used in evaluating the historical, and future agreements between rivers shared countries, and its effects on water shortage values in the studied areas.

Numerical model calibration was the selection to calibrate the numerical model output and even reached to the maximum possible accuracy.

The model was applied after calibration to study future operation scenarios to study the effect of change in well's discharge on the groundwater head through different location.

With increasing extraction in the study area salt water intrusion will happen as shown in Figs. $(12,13)$.

\section{REFRENCES}

1- Abou-Seida M. Mokhles and Abou-Zeid Mahmoud, "Optimal allocation of water resources in the Nile Delta region", water resources management in Egypt, international conference,
Cairo, Egypt, January 11-14, 1981.

2- Abou-Zeid, Mahmoud, "Water resources assessment for Egypt", Water resources development, Vol. 8 No. 2, 1992.

3- Alam, M. Nasr Eldean, "Water and agriculture lands in Egypt, past, present, and future in Arabic", Cairo University, Cairo, Egypt, 2001.

4- Anderson, M.P. and W.W. Woessner, "Applied Groundwater Modeling", 1992, Academic Press, Inc., San Diego, CA., 381 p.

5- Dawoud Mohamed A., and others, "GIS-based groundwater management model for Western Nile Delta", Groundwater institute, National Water Research Center, Egypt, 2005.

6- Ghoneim, A. G. and El-Tarzi A., "Evaluation of Groundwater aquifer in arid region", Eng. Res. Jour., Vol. 56, Faculty of Engineering, Helwan University, Cairo, April 1998.

7- Ghoneim, A., "Development of River Basin Operational Guidelines for Conjunctive Use of Surface and Ground Water", 1988, Ph.D. dissertation, CSU, Ft. Collins, Colorado.

8- Helmy, A., "Integrated Management of Shared River Basin", Faculty of engineering, Zagazig University, Zagazig, Egypt, 2002. 
9- Kamal Hefny, M. Samir Farid, and Mohamed Hussein,

"Groundwater assessment in Egypt", groundwater research Institute, El Kanater El

Khairiya, Egypt, 1992.

10- M. L. Shelton, Journal compilation, 2008, "National Ground Water Association", Volume 20 Issue 1, Pages (86-93), 21 Mar 2006. 